\title{
Analisis Ketersediaan, Kondisi, dan Kendala dalam Penggunaan Media Komponen Instrumen Terpadu IPA di Sekolah Dasar
}

\author{
Siska Angreni ${ }^{a, 1^{*}}$, Rona Taula Sari a \\ a Pendidikan Guru Sekolah Dasar, Universitas Bung Hatta, J1. Bagindo Aziz Chan By Pass, Aie Pacah, Kota Padang 25586, Indonesia \\ 1 siskaangreni123@gmail.com * \\ *korespondensi penulis
}

\begin{abstract}
ABSTRAK
Penelitian ini bertujuan menganalisis ketersediaan, kondisi dan kendala dalam pemanfaatan media Komponen Instrumen Terpadu (KIT) dalam pembelajaran IPA di SD Negeri Kec. Siulak Mukai dan SDN Kec. Siulak. Metode yang digunakan adalah metode deskriptif dengan bentuk penelitian survei. Instrumen yang digunakan lembar observasi dan angket. Hasil penelitian ketersediaan media KIT IPA di SD Negeri Kecamatan Siulak Mukai lebih banyak daripada di SD Negeri Kecamatan Siulak, sedangkan kondisi media KIT IPA di SD Negeri Kecamatan Siulak lebih baik daripada di SD Negeri Kecamatan Siulak Mukai. Ketersediaan dan kondisi media KIT IPA di kedua kecamatan tersebut pada umumnya sudah memungkinkan untuk digunakan dalam proses pembelajaran. Adapun kendala yang di alami dalam pemanfaatan media KIT IPA antara lain sulitnya memilih jenis alat yang akan digunakan serta keterampilan guru yang masih kurang dalam memanfaatkan media KIT IPA.
\end{abstract}

Kata kunci: analisis ketersedian, kendala penggunaan KIT, media KIT IPA

\section{ABSTRACT}

Analysis of Availability, Condition, and Constraints in the Use of Integrated Component Media in Primary Schools. This research aims to analyze availability, condition and the obstacles for utilization the Integrated of Instrument Components media (KIT) the learning of science at Elementary schools in District Siulak Mukai and at Elementary schools in District Siulak. The research applied a descriptive method which included survey forms. Instruments used observation sheets and quesioner. The result of the research showed that the availability of Integrated Instrument Components media (KIT) of natural science at Elementary schools at District Siulak Mukai was much higher than at Elementary schools at District Siulak, while as the condition of Integrated Instrument Components media (KIT) of natural science at Elementary schools in District Siulak was better than at Elementary schools in District Siulak Mukai. The availability and condition of Integrated Instrument Components media (KIT) of natural science in both sub-districts are generally possible to be used in the learning process. The obstacles are founded in the utilization of Integrated Instrument Components media (KIT) of natural science, such as the difficulty in choosing equipment type which will be used. Then, teacher's skills are still lack in utilizing the Integrated Instrument Components media (KIT) of natural science.

Keyword: availability, condition medium KIT natural science, obstacles used medium KIT natural science

Copyright (C) 2017 Universitas Ahmad Dahlan. All Right Reserved

\section{Pendahuluan}

Ilmu Pengetahuan Alam merupakan salah mata pelajaran yang perlu untuk dikenalkan sejak di Sekolah Dasar. Menurut Susanto, (2013) Ilmu Pengetahuan Alam (IPA) berhubungan dengan cara mencari tahu tentang alam secara sistematis, sehingga IPA bukan hanya penguasaan atau prinsip-prinsip saja tetapi juga merupakan suatu proses penemuan. Oleh karena itu, guru harus memberikan kesempatan kepada siswa dalam kegiatan proses penemuan tersebut, salah satunya melalui kegiatan eksperimen. Kegiatan ekpserimen dapat berlangsung dengan didukung melalui pembelajaran IPA karena pembelajaran IPA menekankan pada pengalaman langsung kepada siswa, dimana siswa terlibat aktif terhadap benda-benda dan stimulus-stimulus dengan menggunakan metode ilmiah. Keterlibatan siswa dalam melakukan metode ilmiah pada kegiatan eksperimen merupakan faktor penting yang berpengaruh terhadap kemampuan siswa dalam menerima materi pembelajaran IPA. Dengan demikian siswa dapat membangun sendiri pengetahuannya melalaui berbagai media yang dimanfaatkan dalam pembelajaran IPA. Hal ini menjelaskan bahwa ketersediaan media pembelajaran sangat penting dan berpengaruh terhadap proses pembelajaran IPA.

Peraturan Menteri Pendidikan Nasional nomor 15 Tahun 2010 juga menegaskan bahwa setiap $\mathrm{SD} / \mathrm{MI}$ menyediakan satu set peraga IPA dan bahan yang terdiri dari: model kerangka manusia, model tubuh manusia, bola dunia (globe), contoh peralatan optik, KIT IPA untuk eksperimen dasar dan poster/charta IPA. Penggunaan media pembelajaran IPA dapat membantu guru membawa dunia luar ke dalam kelas. Materi pengetahuan yang bersifat abstrak menjadi konkrit dan mudah dipahami oleh pikiran sederhana siswa. 
Salah satu alat peraga yang sering digunakan dalam kegiatan pembelajaran (praktikum) adalah media Komponen Instrumen Terpadu (KIT) IPA atau science kit. Berbagai penelitian telah menunjukkan bahwa penggunaan KIT sangat membantu dalam pembelajaran karena dapat meningkatkan hasil belajar (Young \& Lee, 2005), dan media KIT dapat menumbuhkan minat serta motivasi siswa (Indayani, 2015; Maryandi, Kresnadi, \& Halidjah, 2013). Selain itu, hasil penelitian terhadap 262 guru sains menunjukkan bahwa penggunaan KIT IPA adalah salah satu faktor yang mempengaruhi pembelajaran sains (Lumpe, Haney, \& Czerniak, 2000) dan penggunaan KIT IPA membuat guru menjadi lebih percaya diri dalam membelajarkan materi (Young \& Lee, 2005). Media KIT IPA sangat penting dalam proses pembelajaran, sehingga mmenjadi kewajiban semua pihak sekolah untuk memastikan ketersediaan dan pemeliharaan kondisi media KIT IPA dengan baik serta memanfaatkannya semaksimal mungkin dalam pembelajaran IPA.

Berdasarkan hasil observasi awal dan wawancara dibeberapa sekolah dasar di Kecamatan Siulak, pada umumnya ketersediaan media KIT IPA masih sangat minim. Ada beberapa alasan yang menyebabkan ketersediaan media KIT jauh dari yang diharapkan, pertama karena ada sekolah yang terbakar sehingga media KIT IPA juga ikut terbakar, kedua, karena sangat jarang sekali dimanfaatkan sehingga media KIT IPA tidak tersimpan dan dijaga dengan baik, ketiga, karena rusak akibat dipakai dan rusak disebabkan tikus dan rayap tetapi tidak dapat diperbaiki. Selanjutnya hasil wawancara dengan beberapa guru yang mengajar mata pelajaran IPA, mereka menyatakan kesulitan memahami penggunaan media KIT IPA, buku panduan yang sudah tersedia kurang dimengerti. Salah satu masalah yang ditemui guru dalam melaksanakan praktikum adalah tidak tahu cara menggunakan alat-alat pratikum (Angreni \& Sari, 2017; Tanang, Djajadi, Abu, \& Mokhtar, 2014). Kemudian guru kurang terampil memilih media KIT IPA yang akan digunakan untuk materi tertentu karena banyaknya komponen yang diperlukan untuk melaksanakan suatu pratikum, dan juga membutuhkan waktu yang relatif lama. Hasil penelitian menunjukkan bahwa guru masih belum memahami dengan benar cara mempergunakan KIT pratikum dan hal ini menyebabkan tingkat keterlaksanaan pembelajaran praktikum menjadi rendah (Rosnita, 2016). Oleh karena itu, penting dilakukan peninjauan kembali ketersediaan dan kondisi media KIT IPA yang diberikan oleh Pemerintah untuk meningkatkan kualitas pembelajaran serta menghimpun informasi kendala yang dihadapi guru dalam menggunakan media KIT IPA pada proses pembelajaran.

\section{Metode Penelitian}

Penelitian ini menggunakan metode deskriptif dengan jenis penelitian survei (Sukmadinata, 2011). Sampel berjumlah 12 Sekolah Dasar di Kecamatan Siulak dan Kecamatan Siulak Mukai dan 72 orang guru yang berada di 12 Sekolah Dasar tersebut, setiap sekolah dasar diwakili oleh 6 orang guru. Instrumen yang digunakan adalah lembar observasi dan angket yang disusun berdasarkan aspek-aspek yang akan diamati. Untuk mengetahui ketersediaan dan kondisi media KIT IPA, maka digunakan lembar observasi. Adapun ketersediaan media KIT IPA yang akan diamati adalah media KIT neraca, media KIT magnet, media KIT pesawat sederhana, media KIT optik, media KIT bunyi, media KIT cahaya, media KIT kalor/panas, media KIT air, media KIT astronomi. Berikutnya kondisi media KIT IPA, aspek yang diamati adalah kondisi baik (bisa langsung digunakan dalam pembelajaran), cukup baik (masih bisa dipakai, namun mengalami kerusakan ringan), rusak (tidak bisa dipakai dalam pembelajaran). Untuk mengetahui kendala yang dihadapi oleh guru dalam menggunakan media KIT IPA, maka digunakan angket. Item-item yang ditanyakan untuk mengetahui kendala yang dialami guru menggunakan media KIT IPA adalah kuantitas menggunakan media KIT IPA, menyesuaikan materi dengan media KIT IPA, menentukan jenis alat yang digunakan, ikut serta pelatihan penggunaan media KIT IPA, terampil menggunakan media KIT IPA, pemahaman terhadap buku petunjuk menggunakan media KIT IPA. Data yang diperoleh kemudian dikelompokkan berdasarkan kriteria 81\% - 100\% (sangat baik), 61\% - 80\% (Baik), 41\% - 60\% (Cukup), 21\% - 40\% (kurang baik), 0\% - 20\% (sangat tidak baik) (Supardi, 2015).

\section{Hasil dan Pembahasan}

Sesuai dengan masalah-masalah yang dikemukan sebelumnya, maka dikumpulkan beberapa data yang mengungkapkan ketersediaan, kondisi media KIT IPA serta kendala yang dialami dalam pemanfaatan media tersebut. Data diperoleh dari hasil observasi, wawancara dan angket diproses dalam pengolahan data.

Berdasarkan pengolahan data lembar observasi tentang ketersediaan media KIT IPA di Kecamatan Siulak Mukai dan Kecamatan Siulak maka diperoleh hasil yang ditampilkan pada tabel 1.

Berdasarkan pengamatan secara langsung dengan menggunakan lembar observasi, diperoleh 
informasi jumlah ketersediaan media KIT IPA di Kecamatan Siulak Mukai lebih banyak dibandingkan dengan jumlah media KIT IPA di Kecamatan Siulak. Meskipun jumlahnya keseluruhannya berbeda akan tetapi jumlah masingmasing media KIT IPA relatif sama. Misalnya ketersediaan media KIT neraca dari kedua kecamatan jumlahnya sama. ada beberapa media KIT IPA yang jumlahnya berbeda yaitu media KIT magnet relatif lebih banyak di Kecamatan Siulak dan media KIT bunyi lebih banyak di Kecamatan Siulak Mukai.

Tabel I. Rekapitulasi ketersediaan media KIT IPA di Kecamatan Siulak Mukai dan Kecamatan Siulak

\begin{tabular}{lcccc}
\hline \multirow{2}{*}{$\begin{array}{c}\text { Nama Media } \\
\text { KIT }\end{array}$} & \multicolumn{2}{c}{$\begin{array}{c}\text { Kecamatan Siulak } \\
\text { Mukai }\end{array}$} & \multicolumn{2}{c}{ Kecamatan Siulak } \\
\cline { 2 - 5 } & Jml & Persentase & Jml & Persentase \\
\hline KIT neraca & 5 & $83,33 \%$ & 5 & $83,33 \%$ \\
KIT magnet & 0 & $0 \%$ & 1 & $16,66 \%$ \\
KIT pesawat & 5 & $83,33 \%$ & 5 & $83,33 \%$ \\
sederhana & & & & $66,66 \%$ \\
KIT cahaya & 4 & $66,66 \%$ & 4 & $33,33 \%$ \\
KIT optik & 3 & $50,00 \%$ & 2 & $66,66 \%$ \\
KIT bunyi & 6 & $100 \%$ & 4 & $50,00 \%$ \\
KIT listrik & 4 & $66,66 \%$ & 3 & $66,66 \%$ \\
KIT astronomi & 5 & $83,33 \%$ & 4 & $83,33 \%$ \\
KIT panas & 5 & $83,33 \%$ & 5 & $66,66 \%$ \\
KIT air & 5 & $83,33 \%$ & 4 & \\
$\quad$ Jumlah & 42 & & 37 & \\
\hline
\end{tabular}

Meskipun ketersediaan media KIT IPA di SDN Kecamatan Siulak Mukai lebih besar dari SDN Kecamatan Siulak. Tetapi jika ditinjau dari kompleksitas, media KIT IPA di SDN Kecamatan Siulak lebih komplek/lengkap dari SDN kecamatan Siulak Mukai hal ini dikarenakan tempat penataan media KIT IPA kurang memadai akibatnya banyak media KIT IPA yang hilang dan dimakan rayap. Selain itu, umur media KIT IPA di SDN di kecamatan Siulak Mukai sudah lama. Media KIT IPA diberikan oleh Dinas Pendidikan lebih kurang 15 tahun yang lalu dan belum pembaharuan untuk pengadaan media KIT IPA tersebut. Selanjutnya, berdasarkan paparan dari beberapa kepala sekolah menyatakan bahwa media KIT IPA tidak terjaga karena sering terjadi perpindahan ruangan dan ada juga sekolah yang mengalami kebakaran. Sehingga ketersediaan media KIT IPA menjadi sangat kurang. SDN di Kecamatan Siulak tempat penataan media KIT IPA pada umumnya sama dengan SDN Kecamatan Siulak Mukai, tetapi di SDN Kecamatan Siulak lebih komplek/lengkap karena ada beberapa SDN yang baru menerima bantuan dari Dinas Propinsi. Sehingga ketersediaan dan kondisi media KIT IPA di SDN tersebut relatif baik. Tetapi pemanfaatan media KIT IPA juga jauh dari harapan, masih banyak guru yang belum memanfaatkan media KIT IPA yang tersedia dalam proses pembelajaran.

Data analisis kondisi media KIT IPA di SDN Kecamatan Siulak Mukai dan kecamatan Siulak ditampilkan pada tabel 2.

Tabel 2. Persentase kondisi media KIT IPA di Kecamatan Siulak Mukai dan Kecamatan Siulak

\begin{tabular}{lcccc}
\hline $\begin{array}{c}\text { Kondisi } \\
\text { Media KIT }\end{array} \quad$ & \multicolumn{2}{c}{$\begin{array}{c}\text { Kecamatan Siulak } \\
\text { Mukai }\end{array}$} & \multicolumn{2}{c}{ Kecamatan Siulak } \\
\cline { 2 - 5 } \multicolumn{1}{c}{ IPA } & Jmlh & Persentase & Jmlh & Persentase \\
\hline Baik & 2 & $4,76 \%$ & 9 & $24,32 \%$ \\
Cukup baik & 25 & $59,53 \%$ & 20 & $54,05 \%$ \\
Rusak & 15 & $35,71 \%$ & 8 & $21,63 \%$ \\
$\quad$ Jumlah & 42 & & 37 & \\
\hline
\end{tabular}

Berdasarkan tabel 2 dapat dilihat bahwa kondisi media KIT IPA di dua kecamatan sangat beragam. Ada tiga indikator yang di amati yaitu kondisi baik (bisa digunakan langsung), kondisi cukup baik (bisa dipakai namun mengalami kerusakan ringan) dan kondisi rusak. Media KIT IPA dengan kondisi baik di SDN Kecamatan Siulak berjumlah 9 media KIT IPA dengan persentase $24,32 \%$ sedangkan di SDN Kecamatan Siulak Mukai hanya 2 media KIT IPA dalam kondisi baik dengan persentase 4,76\%. Kemudian dalam kondisi cukup baik berjumlah 25 di SDN Kecamatan Siulak Mukai dengan persentase $59,53 \%$ dan di SDN Kecamatan Siulak berjumlah 20 media KIT IPA dengan persentase 54,05\%. Selanjutnya dalam kondisi rusak berjumlah 15 di SDN Kecamatan Siulak Mukai dengan persentase 35,71\% sedangkan di SDN Kecamatan Siulak ada 8 media KIT IPA dengan persentase 21,63\%. Dilihat dari kondisi, media KIT IPA di SDN Kecamatan Siulak lebih baik dari SDN di Kecamatan Siulak Mukai. Hal ini diduga karena kepedulian guru-guru serta pimpinan sekolah dalam menjaga media KIT IPA serta memperbaiki media KIT IPA yang rusak.

Guru dalam melaksanakan pembelajaran IPA belum banyak menggunakan media KIT IPA, berbagai kendala yang dihadapi guru tersaji dalam tabel 3.

Tabel 3. Hasil analisis kendala pemanfaatan media KIT IPA di Kec. Siulak Mukai dan Kec. Siulak

\begin{tabular}{lcc}
\hline \multirow{2}{*}{\multicolumn{1}{c}{ Indikator }} & \multicolumn{2}{c}{ Persentase } \\
\cline { 2 - 3 } & $\begin{array}{c}\text { Kec. Siulak } \\
\text { Mukai }\end{array}$ & $\begin{array}{c}\text { Kec. } \\
\text { Siulak }\end{array}$ \\
\hline Kecakapan menyesuaikan materi & $68,75 \%$ & $65,28 \%$ \\
Menentukan jenis alat & $39,55 \%$ & $38,44 \%$ \\
Pemahaman terhadap buku & $54,86 \%$ & $60,64 \%$ \\
petunjuk & $52,24 \%$ & $49,30 \%$ \\
Terampil menggunakan media & $52,08 \%$ & $56,02 \%$ \\
Kuantitas pemanfaatan & $37,19 \%$ & $36,80 \%$ \\
Mengikuti pelatihan & \multicolumn{2}{|}{} \\
\hline
\end{tabular}


Berdasarkan analisis angket pada tabel 3 menunjukkan bahwa kendala yang dialami guru di kedua kecamatan dalam penggunaan media KIT IPA relatif sama. Hasil angket menunjukkan kecakapan menyesuaikan materi dengan media KIT IPA memperoleh persentase yang paling tinggi yaitu SDN Kec.Siulak Mukai (68,75\%) kriteria cukup dan SDN Kec. Siulak $(65,28 \%)$ kriteria cukup, namun pada aspek menentukan jenis alat yang digunakan masih tergolong rendah. Hal ini disebabkan guru sepenuhnya masih kurang paham nama-nama alat KIT IPA tersebut. Sejalan dengan hasil penelitian Jamaluddin et al (2015) yang menemukan bahwa guru juga masih belum memahami penggunaan media KIT. Selanjutnya hasil penelitian Sumintono, Ibrahim, \& Phang, (2010) pada guru-guru IPA yang menunjukkan bahwa guru yang diwawancarai pada penelitian itu mengakui bahwa meskipun siswa senang dengan kegiatan pratikum, penguasaan guru akan alat dan bahan pratikum memang harus diperbaiki untuk menghasilkan kegiatan yang lebih baik.

Hasil tabel 3 menunjukkan bahwa aspek yang memperoleh persentase paling rendah yaitu mengikuti pelatihan penggunaan media KIT IPA dengan persentase $37,19 \%$ di SDN Kec. Siulak Mukai 37,19\% dan 36,80\% di SDN Kec. Siulak. Hal ini membuktikan guru-guru tidak pernah mengikuti pelatihan penggunaan media KIT IPA. Fakta ini senada dengan hasil temuan Rosnita (2016) dan Angreni (2017) hendaknya para pemangku kebijakan memperhatikan kemampuan dan pemahaman penggunaan media KIT IPA misalnya dengan melaksanakan atau memberi pelatihan-pelatihan kepada guru untuk meningkatkan kemampuan dan pemahaman penggunaan KIT IPA dalam praktikum. Pada aspek kuantitas pemanfaatan media KIT IPA di dua kecamatan tersebut memperoleh skor dengan kategori cukup, hal ini disebabkan guru belum memanfaatkan media KIT IPA secara maksimal karena membutuhkan waktu yang relatif panjang serta susah menyiapkan peralatannya, padahal guru sangat paham bahwa penggunaan media KIT IPA dapat memperbaiki kualitas pembelajaran serta meningkatkan hasil belajar siswa. Hal ini sesuai dengan penelitian Eliyadi, Marzuki \& Asran (2013) dalam penelitian tersebut guru yang diwawancarai menjelaskan bahwa siswa sangat antusias dan senang belajar jika menggunakan media KIT IPA dalam pembelajaran.

\section{Simpulan}

Berdasarkan deskripsi hasil penelitian dan pembahasan pada penelitian ini, maka didapat beberapa hal yang dapat dijadikan kesimpulan, diantaranya sebagai berikut. Pertama ketersediaan media KIT IPA di SDN Kec. Siulak Mukai dan SDN Kec. Siulak pada umumnya memenuhi untuk berlangsungnya pembelajaran menggunakan media KIT IPA tersebut, ketersediaan media KIT IPA di Kec. Siulak Mukai jumlahnya lebih banyak daripada media KIT IPA di Kec. Siulak. Jika dilihat dari kondisi media KIT IPA, SDN Kec. Siulak lebih baik daripada SDN Kec. Siulak Mukai. Meskipun demikian media KIT IPA di dua kecamatan tersebut relatif masih kurang atau tidak lengkap. Kedua kendala yang dialami guru dalam penggunaan media KIT IPA diantaranya adalah ketersediaan media KIT IPA yang kurang lengkap, sulitnya memilih jenis alat yang akan digunakan serta keterampilan guru yang masih kurang dalam memanfaatkan media KIT IPA.

\section{Daftar Pustaka}

Angreni, S., \& Sari, R. T. (2017). Ketersediaan dan pemanfaatan media komponen instrumen terpadu (KIT) IPA di SD Negeri Kecamatan Nanggalo Kota Padang. Jurnal Pendidikan Dasar Nusantara, 2(2), 234-242.

Eliyadi, Marzuki, \& Asran, M. (2013). Analisis ketersediaan dan pemanfaatan media pembelajaran IPA kelas VI SDN Kecamatan Tebas. Jurnal Pendidikan dan Pembelajaran, 2(9), I-I6.

Indayani, L. (20I5). Peningkatan prestasi belajar peserta didik melalui penggunaan media KIT IPA di SMP Negeri IO Probolinggo. Jurnal Kebijakan dan Pengembangan Pendidikan, 3(I), 54-60.

Jamaluddin, J., Kade, A., \& Nurjannah, N. (20I5). Analisis pelaksanaan praktikum menggunakan KIT IPA fisika di SMP Se-Kecamatan Sojol Kabupaten Donggala. Jurnal Pendidikan Fisika Tadulako Online (JPFT), 3(I), 6-I3.

Lumpe, A. T., Haney, J. J., \& Czerniak, C. M. (2000). Assessing teachers' beliefs about their science teaching context. Journal of Research in Science Teaching, 37(3), 275-292.

Maryandi, R., Kresnadi, H., \& Halidjah, S. (2013). Penggunaan KIT IPA pada materi energi panas terhadap hasil belajar siswa kelas IV SD. Jurnal Pendidikan dan Pembelajaran, 2(8).

Rosnita. (2016). Keterampilan guru dalam melaksanakan praktikum dengan menggunakan Komponen Instrumen Terpadu (KIT) IPA SD. Jurnal Pengajaran MIPA, 2I(I), IO3I06.

Sukmadinata, N. S. (20II). Metode penelitian 
pendidikan. Bandung: PT Remaja Rosda Karya.

Sumintono, B., Ibrahim, M. A., \& Phang, F. A. (2010). Pengajaran sains dengan praktikum laboratorium: Perspektif dari guru-guru sains SMPN di kota Cimahi. Jurnal Pengajaran Matematika dan Ilmu Pengetahuan Alam, I5(2), I20-I27.

https://doi.org/I0.18269/jpmipa.vI5i2.29I

Supardi. (2015). Penilaian autentik (Pembelajaran afektif, kognitif, dan psikomotor). Jakarta: PT Raja Grafindo Persada.

Susanto, A. (2013). Teori belajar dan pembelajaran di Sekolah Dasar. Jakarta: Kencana Prenada Media Group.
Tanang, H., Djajadi, M., Abu, B., \& Mokhtar, M. (20I4). Challenges of teaching professionalism development: A case study in Makassar, Indonesia. Journal of Education and Learning, $8(2)$, I32-I43.

https://doi.org/http://dx.doi.org/I0.I I59I /edulearn.v8i2.2I5

Young, B. J., \& Lee, S. K. (2005). The effects of a kit-based science curriculum and intensive science professional development on elementary student science achievement. Journal of Science Education and Technology, I4(5-6), 47 I-48I. https://doi.org/I0.1007/sI0956-005-02222 